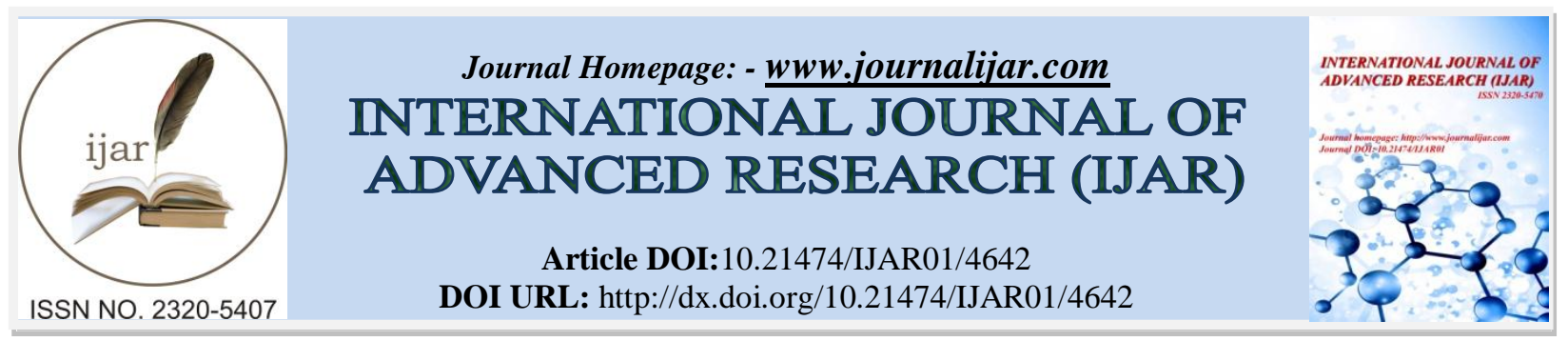

RESEARCH ARTICLE

\title{
EVALUATE THE EFFICACY OF DEVELOPED MATERIAL BASED ON PROGRAM LEARNING FOR LEARNING DISABLED STUDENTS OF SECONDARY SCHOOLS.
}

\section{Dr. Sumati Rani ${ }^{1}$ and Prof. Archana Kapoor ${ }^{2}$.}

1. Assistant Teacher, Dept. of Education, Government Girls Inter College, Parkham, Mathura, India.

2. Dept. of Pedagogical Sciences, Faculty of Education, Dayalbagh Educational Institute, Dayalbagh, Agra, India.

\section{Manuscript Info}

[.........................

Manuscript History

Received: 28 April 2017

Final Accepted: 30 May 2017

Published: June 2017

Key words:-

Learning disabled students, Self -

Instructional Material (SIM)

\section{Abstract}

The purpose of the research was to study the efficacy of developed material based on program learning for learning disabled students of secondary schools. A sample of 14 girl students studying in secondary schools of Agra city was purposively selected after identifying the learning disabled students. The researcher used the self-constructed tool achievement test and developed material (SIM based on program learning) for this study. In statistical techniques, Mean, S.D. and t-test were calculated to analysis the data. The study concludes that developed material based on program learning was significantly increased the achievement of the learning disabled students of secondary schools.

Copy Right, IJAR, 2017,. All rights reserved.

\section{Introduction:-}

The learning disabled students occupy no specific place in centrally sponsored scheme of integrated education for disabled students. This speaks of the extent to which learning disabilities are ignored and the problems not tackled. Sakhuja (2004) Specifies that 'Education for all' still remains a distant dream for disabled and is even worse in India. She reported in her study that in India around 13-14\% of all school students suffer from learning disorders. Unfortunately, most schools fail to lend a sympathetic ear to their problems. As a result, these students are branded as failures. The schools are full of students, but these schools only focus on their objectives such as increasing the number of students, they do not want the quality in knowledge and education. These schools cannot fulfil the needs of students and they blame the students. Sharma (1999) showed that there are three main activities which are needed in education process- teaching, instruction and training. Once the pupil is identified the special help should begin. It will help him to benefit from the normal activities of the school, if the learning disability is mild. One of the widely accepted facts is that individualized instruction is of much use to the learning disabled. Anette (2010) conducted a study on learning difficulties and academic competence among children with and without learning disabilities, Sara (2010) promoting social and academic competence in the classroom: an intervention study examining the contribution of the responsive classroom approach, De La (2009) examined the use of a self-monitoring treatment package to support teacher in developing and implanting self-monitoring intervention for LD students, Ray (2008) conducted a study on evaluate the efficiency of the development algebraic literacy model for learning disabled students, Russel (2007) studied a meta -analysis on writing interventions for students with learning disabilities, Daqui (2000) studied on effect of story mapping and story map questions on the story writing performance of students with learning disabilities, Pandit (2000) conducted a study on factors affecting learning disabilities in mathematics in central region of Nepal, a descriptive study of teaching strategies used by general education teacher in classroom including students with mild learning disabilities, Bayer Stephen (2003) and Mathew (2003) examined India. 
the effectiveness of SIM and modern teaching strategy in minimizing learning disabilities of Biology students in secondary school, It was inferred from these studies that learning disabled students have unique educational and psychological characteristics therefore inventories, strategies and planning are necessary for lifting the LD students to enhance their academic achievement and competence to make them independent. From the review of related literature the researcher found that there was no instructional material on learning disabilities in Home Science. Therefore the researcher embarked on this research work to fill the gap and facilitate learning disabled students of Home Science.

Objective of the study:-

The Objective of the present study is following as:

To study the efficacy of developed material based on program learning for learning disabled students of secondary schools.

\section{Methodology:-}

Sample: The present study deals exclusively with learning disabled populations and the purposive sampling method has been used for selection of the sample.A sample of 14 girl students studying in secondary schools of Agra city was purposively selected after identifying the learning disabled students $(\mathrm{N}=200)$.

Design of the Study: In the present study, descriptive survey method was used.

Tools \& Techniques of Data Collection: These following self-constructed tools were used in the study:

- $\quad$ Achievement test in Home Science (ATHS)

- Developed material -SIM based on program learning (Self Instructional Material)

Achievement test was based on content. The test-retest method was used to estimate reliability of the test. Product moment method was used for calculating reliability and the obtained score is 0.85 . This obtained value shows very high reliability. SIM was basically designed in the form of programmed learning based instructional material. It was considered appropriate to follow linear programming as given by B. F. Skinner. The frames consisted of stimuli that called for a specific action or set of actions, the learner was to perform after learning from the program.

The researcher decided to prepare the topics by analyzing the contents that suit the needs of the students with learning disabilities. The content was analyzed in terms of behavioral objectives. The learning material was then divided into frames. Each frame was a small segment of subject matter that called for particular student responses. Frames are presented in units and subunits.

The units are divided into sections for easy reading and better comprehension. For purpose of uniformity the researcher has employed the same scheme of 'partitioning' in every unit. Self-check exercise under the section 'Check Your Progress', have been provided at two / three places in each unit and model answers at the end of each unit. Prompts were provided on the program frame to guide the student for making correct response. In the last section of each unit, under the heading 'Let us sum up,' the whole unit was summarized for purpose of recapitulation and ready reference. The material was provided with activities and experiments to be performed by the students so that the scientific attitude and critical thinking could be developed. These activities also encourage them to have interaction with the teachers and classmates. After each sub-unit and content, formative evaluation questions were given so that the students could check themselves before proceeding to the next unit. SelfInstructional material was administered on small group of learning disabled students. To gauge their understanding of the subject matter post -test was administered thereafter. The scores of this post achievement test were compared with their pre achievement scores.

Statistical techniques used:-

Mean, S.D., and t-test were calculated to analysis the data.

\section{Result and Discussion:-}

The data collected is tabulated and the results obtained are presented and discussed in following manner:

Table 1:- Exhibiting Scores of Pre and Post Achievement Test in Home Science of LD students.

\begin{tabular}{|c|c|c|c|c|c|c|}
\hline S. No. & Test & Group & Mean & SD & t-Test & Level of significance \\
\cline { 1 - 4 } 1. & Pre & LD Students & 1.92 & 0.70 & 5.5 & \\
\cline { 1 - 1 } & Post & $(\mathrm{N}=14)$ & 6.71 & 0.95 & & \\
\hline
\end{tabular}


The above table exhibits that Score of students in home science achievement test was increased in reference to pre and post- test after administering the developed material based on program learning. Mean value of pre score test is 1.92 which increased in post score with 6.71. The t- test value of pre score and post score of achievement of LD students in home science was found 5.5. t-test value was found significant at 0.01 level i.e 3.01 and at 0.05 level i.e. 2.16 which shows highly significant difference between pre and post score of achievement test of LD students in home science. It is further inferred that Pre-test shows that learning disabled students who had low scores (27) when administered developed material their post scores has changed significantly (94). Significant difference between pre and post shows the efficacy of developed material in increasing the academic achievement and its efficacy among LD children. This result has found support in the following research Russel (2007) revealed that the interventions used in the research studies constantly produced strong effects on the quality of students' writing as well as students' efficacy and understanding of the writing process.

\section{Conclusion:-}

The study concludes that students were taught using developed materials for 15 days. Thereafter, the post test was administered to students. Mean value of post test was found significantly increased. t-test value was also found highly significant. On this basis, it can be inferred that the developed material based on program learning effectively increase the achievement of learning disabled students. The result indicated that strategy instruction improved the performance of students with learning disabilities. Similar inferences were also drawn by Pandit (2000) regarding mathematics teaching.

\section{References:-}

1. Anette, C., Inverson (2010). Learning Difficulties and Academic Competence among Children With and Without Learning Disabililties. Canadian Journal of Experimental Psychology, Vol.66 (3).

2. Bayer, Stephen. (2003). A Descriptive Study of Teaching Strategies Used by General Education Teacher in Classroom Including Student Mild Learning Disabilities, Dissertation Abstracts International (2005), Vol. 65 (8). University Microfilms International Ann Arbor Michigan, U.S.A.

3. Daqui. (2000). Effect of Story Mapping and Story Map Questions on the Story Writing Performance of Students with Learning Disabilities. Dissertation Abstracts International (2000), Vol. 61, (4). University Microfilms International Ann Arbor Michigan, U.S.A.

4. De., La., Cruz., Berenice (2009). Use of a Self-monitoring Treatment Package to Support Teacher in Developing and Implementing Self-monitoring Intervention for LD Children. Dissertation Abstracts International (2010) Vol. 70, (9). University Microfilms International Ann Arbor Michigan, U.S.A.

5. Krouse, J. and Kauffman, J.,M. (1982). Minor Physical Abnormalities and Exceptional: A Review and Critique of Research. Journal of Abnormal Child Psychology, Vol.10, (2).

6. Lee. (2000). A Meta-analysis of Mathematics Interventions Reported for 1971-1998 on The Mathematics Achievement of Students Identified with Learning Disabilities and Students Identified as Low Achieving. Dissertation Abstracts International (2000), Vol. 61, (2). University Microfilms International Ann Arbor Michigan, U.S.A.

7. Lindsay. (2004). A Case Study of the Annual Review Meeting as a Forum for Developing Individualized Education Program for Elementary School Students with Disabilities As Perceived by Professional Members of Individualized Education Program. Dissertation Abstracts International (2004), Vol. 65, (9). University Microfilms International Ann Arbor Michigan, U.S.A.

8. Mathew, A. (2003). Effectiveness of Self Instructional Material and Modern Teaching Strategies in Minimizing Learning Disabilities Students in Secondary School. Mahatma Gandhi University. Kottyam. Trivananthpuram.

9. Pandit, R.P. (2000). A Model for the Identification of Learning Disabilities in Mathematics. Shikshak Journal. Mahendra Ratna Campus. Kathmandu. Vol. 3.

10. Ray, Sharon (2008). Evaluating the Efficiency of the Developing Algebraic, Literacy Model: Preparing Special Educators to Implement Effective Mathematics Practices, Sharon N.E Ray, University of South, Graduate School Theses and Dissertation. Forida.

11. Russel (2007). A Meta-Analysis: Teaching Expressive Writing to Students with Learning Disabilities. www.jstor.org

12. Sakhuja, S. (2004) Education for All and Learning Disabilities in India. Article 9 (http://www.msub.ed.)

13. Sara, E. Rim. Kaufman. (2010). Promoting Social and Academic Competence in the Classroom: An Intervention Study Examining the Contribution of the Responsive Classroom Approach, Psychology in the School Vol. 44, (4). 
14. Silver, N.J. (1990). Attention Deficit- Hyperactivity Disorder: Is it a learning disabilities or a related disorder? Journal of learning disabilities, Vol. 23.

15. Singh, R.K. (1981). Peer Tutoring, Its Effect on the Math Skills of Students with Learning Disabilities. The American University, (1981). Dissertation Abstracts International (1983) Vol. 54, (4). University Microfilms International Ann Arbor Michigan, U.S.A.

16. Smith, D.H. (1986). Teaching the Learning Disabled. Prentice-Hall, Englewood Cliffs.

17. Swanson, H.L. (1987). Information Processing Theory and Learning Disabilities: An Overview. Journal of Learning Disabilities Vol. 20, (1). 